\title{
Auctions, Ex Post Competition and Prices: The Efficiency of Public-Private Partnerships*
}

\author{
Eshien CHONG \\ ADIS - U. of Paris 11 \& ATOM - U. of Paris I Sorbonne \\ Freddy HuET \\ ATOM - U. of Paris I Sorbonne \\ Stéphane SAUSSIER \\ ADIS - U. of Paris 11 \& ATOM - U. of Paris I Sorbonne
}

December $23^{\text {rd }}, 2005$

\begin{abstract}
Using an original database concerning 1637 French local public authorities in 2001, we explore the relationships between prices charged by private operators in water contracts and ex post competition. We show that prices charged in contracts in which operators are in a monopoly situation throughout the duration of the contract, are not affected by a "competition effect" between private operators. However, a competition effect between private operators and public management appears to be crucial in explaining prices combined with a "termination effect", reflecting the fact that the contract is close to being renewed, and hence re-auctioned.
\end{abstract}

Key Words: public services, Contractual choices, Franchise bidding, Public-Private Partnerships, Competition and prices, Concession Contracts.

JEL Codes: H0, H7, K00, L33

\section{Introduction}

There has been a growing amount of literature on the difficulties associated with the « franchise bidding» solution initially proposed by Chadwick (1857) and popularized by Demsetz (1968). This literature challenges the idea that public utility services can be efficiently procured simply by awarding a franchise to the firm that offers to serve the market at the lowest price. As pointed out by transaction cost economics, by advocating a hybrid organizational structure this organizational solution does not avoid market and public failures (Williamson 1976, Goldberg 1976) mainly because many of the problems associated with regulation or privatization lie in the characteristics of the transaction of what is being regulated, not in the act of regulation or privatization itself.

\footnotetext{
* We would like to thank Paul Joskow, Yannick Perez, Faye Steiner for their comments and all the participants at the Isnie Conference held at the University of Pompeu Fabra in 2005.
} 
In this respect, one of the main concerns of the transaction cost economics framework is the competition level at stake in these franchise contracts. At the ex ante stage, the auction procedure and its result are crucial. Since all long-term contracts are inevitably incomplete, auctioning procedures are not always effective in identifying the most efficient private operator to invest and operate a public service. The "winner's curse", as well as ex ante opportunism may disturb the result of the auction (Williamson 1976, Klein 1998). Deciding ex ante what has to be done ex post is a way to stabilize the contract by avoiding (as much as possible) renegotiations during which opportunistic behaviors may appear. However, stability is obtained at the cost of making the contract maladapted to unanticipated circumstances (Crocker-Masten 1991, Crocker-Reynolds 1993, Saussier 2000, Athias-Saussier 2005), and over-evaluating prices because competitors will want to anticipate transaction costs associated with renegotiations and conflicts (Bajari-Houghton-Tadelis 2004). Finally, the franchise bidding procedure appears to be inefficient or at least a very expensive way to ensure that the private operator will invest until the end of the contract, especially when he knows that the term of the contract will not provide him with a fair return on his investment since he gives up operation rights at the end of the contract (Chong-Huet 2005). ${ }^{12}$

It follows that because renegotiations inevitably occur, the level of competition is also important at the ex post stage, and may have an impact on the efficiency of such franchise contracts. The importance of the contract for the operator and the possibility of repeated transactions may reduce opportunistic behavior. From this perspective, formal ex ante competition through auctioning and informal ex post competition may be complementary mechanisms (Gibbons 2005, Poppo-Zenger 2002). To our knowledge, the impact of competition on the ex post stage of the franchise bidding process has not yet been analyzed. This is unfortunate since what has been decided during the ex ante auction procedure stage might not ultimately be applied because of the renegotiation process at the ex post stage (See Guasch 2004 and Guash-Laffont-Straub 2004 for empirical evidence of the high frequency of renegotiation in concession contracts). Renegotiation might be "constrained" by the level of ex post competition. Therefore, implicit relationship dimensions, like ex post effective

\footnotetext{
${ }^{1}$ This is a crucial point in the French case because investments made by the operator in a lease or concession contract are transferred to the public authority at the end of the relationship, generally without any financial compensation.

${ }^{2}$ See Affuso and Newbery 2000 for a different point of view. They argue that investing just before the end of the franchise contract may be a good strategy for contractors because it would raise entry costs for other potential bidders and increase the incumbent's probability of being re-awarded the contract.
} 
competition, could play a role in the efficiency of such contracts. This is the main question we will in this paper.

We study the case of the water supply in France using an original database of 1637 French municipalities, corresponding to 43 French regions, for which we observe contractual choices and prices in force in 2001. This case is particularly interesting because 1993 anti-corruption laws required recent contracts to be auctioned. Thus, we have contracts signed during a period when negotiation is the default rule as well as when auction is the default rule and we can assess the change in observed prices in the water supply. Nevertheless, we show that contracts signed before and after the French law regarding auctioned public services, exhibit the same ex post problems (i.e. renegotiation) and that such a law does not have a dramatic impact on observed prices. This first result reinforces our view of the importance of the ex post stage of the contract. We then assess the importance of ex post competition level once the contract has been signed by constructing Herfindahl indices for each region. Our results show that a "competition effect" only exists between private operators and public management. We were not able to find any impact of the competition between operators on prices. This competition effect is completed in addition with a "termination effect". More precisely, when private operators are awarded a monopoly while the contract is in force, the greater the ex post competition level between private operators and public management and the closer the contract's expiry date, the lower the observed price for customers will be. We believe this can be interpreted as a measure of the value of prospective future transactions for the private operator, limits opportunistic behaviors through the ex post renegotiation process (i.e. limit price increase) because of his desire to have the contract renewed by the municipality. Furthermore, our analysis questions the relative superiority of public management concerning prices found in other articles that did not take ex ante or ex post competition levels into consideration.

We proceed as follows. In the first section, we review the characteristics of the French case and present our propositions. In the second section, we use our data to test the propositions. Conclusions follow. 


\section{Organizational choices, ex post environment and prices in the French water supply industry: propositions}

\subsection{A wide range of organizational choices}

In France, as in most European countries, local public authorities ${ }^{3}$ are in charge of the organization of local public services. More precisely, they are responsible for the existence and the operation of these services. The reason for this is that these activities have general interest attributes that prevent them from being provided through a private competitive market. Privatization is not an option by laws. As the organizer of the local public service, local public authorities must define the general principles governing the service. There is no national regulator for these services.

Nevertheless, if the organization of the activity is public, the management of the service can be either public (direct management), or private (for more details see Huet-Saussier (2003)). Therefore, local public authorities may decide to cooperate with an external operator. ${ }^{4}$ If the municipality retains this option, it will have a wide variety of contractual arrangements at its disposal. There are several types of contractual arrangements that differ according to the degree of the firm's involvement in the service (who makes the investments) and the proportion of the risk that the external operator bears (how the operator is paid). The "gérance" contract is closest to direct public management. The operator only manages the service (no investment) and is paid a fixed amount by the public authority. The "intermediary management" contract has almost the same contractual arrangement as the "gérance" contract, except that a part of the operator's revenues depends on his performance. Finally, two types of "delegated management contracts" differ from these other contractual arrangements in how they compensate operators and in the investments borne by operators. In the lease contract the municipality and the operator both invest but the most important investments usually remain public. In this type of contract, the operator is no longer paid by the municipality but rather by customer's receipts. In the concession contract the operator bears more risk to the extent that he is responsible for the investments made over the duration of the contract. The investments made by the operator in a lease or concession contract are transferred to the public authority at the end of the contract, generally without any financial compensation.

\footnotetext{
${ }^{3}$ Essentially, the authorities are municipalities or trade unions comprised of several municipalities.

${ }^{4}$ This is generally, but not necessarily, a private firm.
} 
The French system, due to the variety of contractual and governance arrangements provides an exciting laboratory in which to analyze the links organizational choices made by local public authorities providing public services and performance.

\subsection{Potential problems associated with PPP: the ex post stage}

Replacing "market failures" with "regulation failures" may be avoided even when competition within the market is impossible if it could be replaced with competition for the market, via a contractual arrangement between a public and a private agent. This idea, developed by Demsetz (1968), has since been challenged by many authors arguing that such a contractual arrangement is also characterized by many "failures" that may exceed those identified with public ownership, regulation or the market.

These problems have been identified by transaction cost economics (Williamson (1976) and Goldberg (1976)). As noted by Littlechild (2002), “The Williamson-Goldberg view seems to have prevailed, at least in the economic literature" (page 4) even if subsequent empirical tests did not conclude in favour of such arguments (for example Zupan (1989 a,b).

Problems with the use of public-private partnerships stem from the fact that there may be positive and even high transaction costs associated with the provision of certain kinds of services.

A public-private partnership is characterized by three different stages, each of which may generate problems. At the beginning of the process, choosing the operator may be problematic since the initial award may often need to include not only one price, but a vector of prices to be determined depending on the types of clients or level of quality. Furthermore, if operators are selected based on their price bids, then there is risk of "winner's curse", since the best offer may come from the most optimistic operator. Contracts of endogenous duration may offer a partial solution to this problem (Engel-Fisher-Galetovic (1997). This leaves open the question of how to best generate the type of competition for the field that will lead to the most efficient concession contract. ${ }^{5}$ This also raises the question of investment decisions and their repartition over the contract's duration. Many of the problems with concession contracts are associated with long term contracting and specific investments. Public authorities may decide to bear specific investments and sign a short-term agreement for operating the service or they

\footnotetext{
${ }^{5}$ See for example Bajari-McMillan-Tadelis (2003) on this issue, who show that, in many cases, negotiation is better than a bidding process to choose the operator
} 
may decide to sign two contracts: one contract for investments in infrastructures and the other for operating the service (See Hart (2003)).

Once the operator is chosen, since "all complex contracts are unavoidably incomplete, the parties will be confronted with the need to adapt to unanticipated disturbances by reason of gaps, errors, and omissions in the original contract" (Williamson (2002)). This is especially true when the contracting parties are confronted with uncertain environments leaving room for opportunistic behavior.

Lastly, at the contract renewal stage, the winner of the original competition retains an advantage because of the "fundamental transformation" that gives rise to specific human assets for the winner versus other potential bidders. Furthermore, there is a greater likelihood that the previous winner is the most informed with regard to the cost of service provision and the amount of investments needed in the future to operate the service. In such a context, the incumbent, who operated the service in a monopoly situation for an extended period of time, clearly has an informational advantage.

Thus, in the transaction cost approach, the ex post stage of contracts is crucial. In particular, because long-term contracts are inevitably renegotiated, additional institutional frameworks as well as the level of ex post competition are important and may have an impact on the efficiency of such franchise contracts. We now turn to the specific institutional framework for French water contracts.

\subsection{A specific institutional framework}

Problems associated with franchise bidding, and more generally public-private partnerships, are unavoidable but are not necessarily important enough to disqualify this governance structure for public services. Institutional and contractual solutions exist that may reduce problems that stem from transaction costs (Littlechild (2002)).

As we already noted, the French case is characterized by a great deal of flexibility in organizational choice for the provision of local public services. Nevertheless, it should be noted that the institutional framework in which this same freedom of choice is embedded amplifies the discretionary power of local public authorities through the "intuitu personae" 
principle $^{6}$. Furthermore, the fact that such contracts are considered to be "administrative contracts" also gives great power to the public contracting party as we explain below.

\subsubsection{Negotiation and competition for the field: the "intuitu personae" principle}

If the public authority chooses a lease or a concession contract, the mechanism of selection of its partner consists of a two-step procedure:

- In the first step, the public authority chooses a certain number of potential candidates using a classical competitive tendering process.

- In the second step, there is a phase of negotiation between the public authority and the potential providers. At the end of the negotiation, the public authority chooses its final partner for the duration of the contract.

What is important here is that the municipality is not obliged to select its partner by complying with the objective criteria defined by law, as would be the case in a strict competitive tendering process. The existence of this two-step procedure gives the public authority latitude to select its partner freely, using objective but also subjective criteria that are not necessarily specified by law. Furthermore, the local public authority need not justify its decision to organize the service through a public private partnership or through direct public management. ${ }^{7}$

\subsubsection{PPP and the rules of administrative contracts}

Contracts signed between local authorities and private operators are considered to be "administrative contracts". Such contracts are characterized by an asymmetric position between the public and the private contracting parties in which the local authority may unilaterally change the contract's terms after it is signed. Of course, such changes must be justified (by public safety for example) and the private operator may claim fair compensation.

\footnotetext{
${ }^{6}$ A contract concluded "intuitu personae" is a contract involving a customized relationship between the buyer and the seller. Employment contracts and mandates are examples of "intuitu personae" contracts. For example, an employer is not obliged to engage the candidate with the highest qualifications who is willing to accept the lowest wage, but may also consider intrinsic characteristics of the candidates themselves (dynamism, kindness, ability to communicate with colleagues, customers etc.) before deciding whether or not to employ a candidate. These features cannot be incorporated into a contract and are not verifiable by a court. The same reasoning applies to a local public authority choosing a firm within the framework of a régie intéressée (defined below), a lease or a concession contract.

${ }^{7}$ Flexibility is not necessarily less efficient. It may helps to overcome many of the problems identified concerning the choice of the operator in a more rigid franchise bidding process (Bajari-McMillan-Tadelis (2003)).
} 
Nevertheless, in case of conflict, the private operator must conform to the wish of the local authority first before bringing the conflict to court. In practices, local authorities do not often use this power. Nevertheless, it provides a credible threat that helps to prevent the private operator from acting opportunistically, because it generates fear of the contract being terminated prematurely or changed unilaterally.

\subsubsection{A specific institutional framework that evolved through time}

\section{Evolution toward freedom}

There has been an evolution toward more freedom for local authorities that resulted from the Decentralization Laws in 1982. Before this date, local authorities could not choose their contractual provisions. Compulsory and standardized lease and concession contracts contained few incentives for private operators to meet quality constraints (See Ménard, Staropoli and Saussier (2003)). After this date, local authorities were able to choose their own contractual provisions. We thus hypothesize that prices in contracts signed before 1982 should higher than those signed after because the latter are more "fitted": they may limit ex post opportunism to the extent that municipalities are rational enough to choose efficient contractual terms. ${ }^{8}$

\section{Evolution toward anti-corruption laws}

As of 1993, under the Anti-Corruption Law (Loi Sapin), local authorities have been required to advertise their willingness to contract out the provision of local public services and to organize an auction for interested candidates. Nevertheless, as we argued earlier, the intuitu personae rule implies that local authorities are not obliged to choose the best offer. Thus prices may be lower for contracts signed after 1993, compared to those signed before, to the extent that anti-corruption laws lead to increased ex ante competition (i.e. reduced discretion for local authorities).

The question of the impact of the evolution of the French institutional framework on observed water prices is clearly beyond the scope of this paper. Nevertheless, it deserves special attention and we will control for the date of signature of contracts in our econometric tests.

\footnotetext{
8 We retain the assumption that municipalities are looking for efficient agreements to reduce prices (if one considers that such contracts are characterized by other objective functions, this might not be the case)
} 


\subsection{Prices and ex post competition in franchised contracts}

The three main private operators on the market have more than $90 \%$ of the total market. This suggests that there may be a low level of ex ante competition and also a low level of ex post competition, especially at the time of contract renewal or during ex post renegotiations. ${ }^{9} 10$ But, even if during the contract the operator has a monopoly over the service he is providing, the more intense the potential competition is, the more he should react to local authority demands during the contract (and most especially when renegotiation occurs) in order to maximize his chance of renewing the contract.

Competition levels vary across the different French geographical areas. Graph 1 shows the geographical repartition of firms in 25 French regions (over the 43 regions represented in our sample) in 2003.

\section{Graph 1. Geographical repartition of French firms in 25 regions}

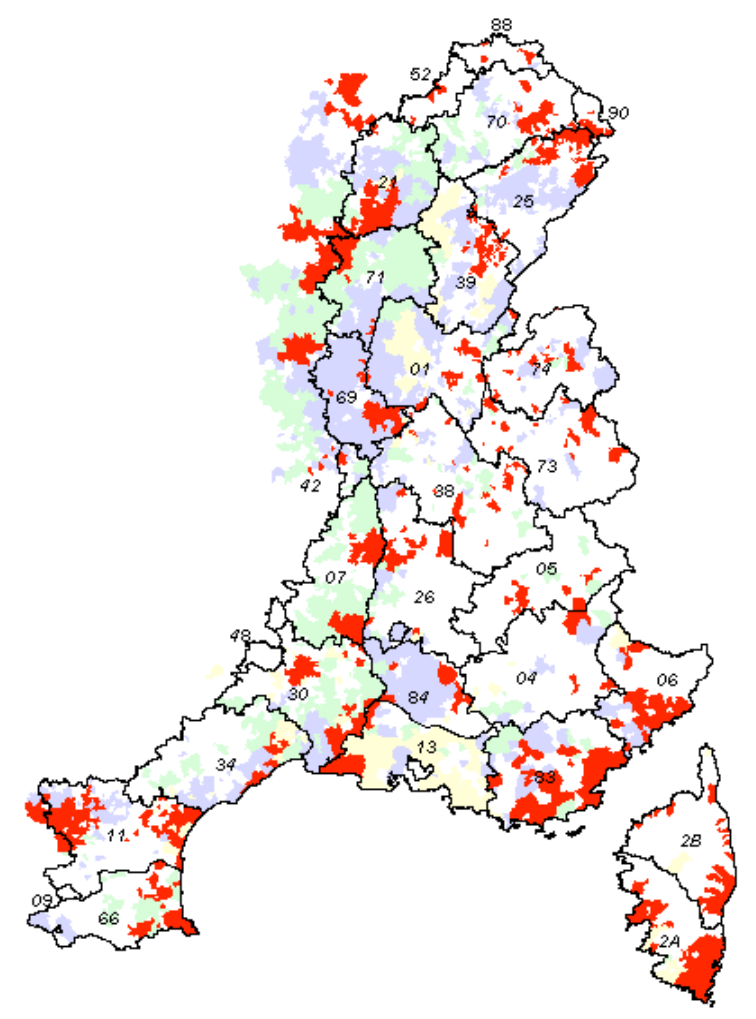

Market shares of each water company in 25 regions representing 13.6 million inhabitants

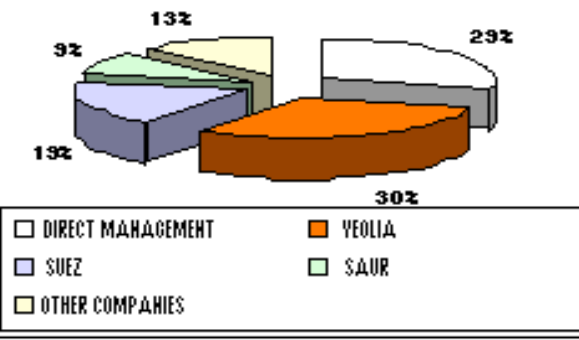

Source: French Water Agency Rhône-Méditerranée-Corse 2003

We can see that some regions are dominated by one firm $(13,69,84)$ while others contains many firms $(1,21,30)$. Some regions are very rich in public management $(4,38,90)$ while

\footnotetext{
${ }^{9}$ Only $11 \%$ of renewed contracts in 2001 were not resigned with the same operator.

${ }^{10}$ This argument often explains why observed average prices are lower in direct public management cases than PPP cases (Chong-Huet-Saussier 2005).
} 
others are very poor $(84,71)$. We will use the Herfindahl indices to show the impact of firm participation on the price of water paid by consumers.

The level of ex post competition may impact the efficiency of franchise contracts because the importance of the contract for the operator and the perspective of repeated transactions may reduce opportunistic behavior when competition exists (Gibbons (2005), Poppo-Zenger (2002)). At the same time, competition increases outside options for local authorities. Furthermore, this competition effect intensifies as the contract approaches its end particularly as firms face the credible threat of not having a contract renewed.

This leads us to two propositions concerning ex post competition and prices in water contracts.

Proposition 1: Prices should be lower for contracts signed in geographical zones where potential competition between private operators (or between private operators and public management) exists. This is a "competition effect".

Proposition 2: The "competition effect" should increase with the proximity of the renewal of the contract. This is a "termination effect".

These propositions highlight the fact that the ex post level of competition constrains the behavior of the private operator especially in the dynamic perspective of winning future contracts to be awarded. ${ }^{11}$

\section{Data \& Results}

\subsection{The sample}

Our sample is a combination of two samples.

- A first sample of 5000 municipalities observed in 2001 -reduced to 4370 usable observations- $-^{12}$ with information concerning water networks, organizational choices and prices. Data comes from the French Environment Institute (IFEN), the French Ministry of Agriculture and the French Health Ministry (DGS). This is

\footnotetext{
${ }^{11}$ One may say that contracts are awarded through competitive auctions and that past observed prices should not have an impact on the probability of being retained at the renewal stage. Nevertheless, such a remark omits the "fundamental transformation" highlighted by transaction cost economics (Williamson 1985) and the "intuitu personae" principle that makes future competitive auctions dependent on past observed behaviours.

${ }^{12}$ Water production and water distribution may be organized differently. The price of the water is explained by those two elements. We restricted our initial sample to the cases where production and distribution are organized through the same organizational choice. This leads us to 4370 observations.
} 
a representative sample of the total population of French municipalities (all sizes of local authorities are proportionally represented in the sample, with the exception of large local authorities who are all included in the sample).

- We then merge this with data from French Water Agencies to assess the degree of ex-post competition. We calculate market shares of each water company across all 43 French regions, representing approximately 16000 municipalities and almost 20 million inhabitants, or one-third of the French population. The market shares are calculated using the percentage of the population in a department that receives water from a given company.

Merging these two databases, we were able to create a sample of 1637. Table 1 gives us the distribution of organizational choices in both the large and the merged samples.

Table 1: distribution of organizational choices

\begin{tabular}{|c|c|c|c|c|}
\hline \multirow{2}{*}{ Organizational Choices } & \multicolumn{2}{|c|}{ Whole sample } & \multicolumn{2}{c|}{ Merged samples } \\
\cline { 2 - 5 } & $\boldsymbol{N}$ & $\boldsymbol{F r e q}$ & $\boldsymbol{N}$ & Freq \\
\hline Direct Public Management & 1607 & 0,37 & 618 & 0.38 \\
\hline Lease & 2288 & 0,52 & 935 & 0.57 \\
\hline Concession & 170 & 0,03 & 47 & 0.02 \\
\hline Intermediary management & 137 & 0,03 & 2 & 0.001 \\
\hline Gerance & 168 & 0,03 & 35 & 0.02 \\
\hline Total & 4370 & 1 & 1637 & 1 \\
\hline
\end{tabular}

Source: IFEN and French Water Agencies

We observe that there is no difference across samples in the representation of the main organizational choice alternatives (Direct public management, Lease and Concession).

\subsection{A diversity of organizational choices resulting in a diversity of prices}

A first look at the link between prices and organizational choices shows that direct public management may be advantageous, even if the impact of organizational choices on prices would require more careful assessment (Table 2). 
Table 2. Prices and organizational choices

\begin{tabular}{|c|c|c|c|c|c|}
\hline \multirow{2}{*}{ Organizational Choices } & \multicolumn{5}{|c|}{ Prices in 2001 (merged sample) } \\
\cline { 2 - 6 } & Mean & Std Deviation & Min & Max & $\boldsymbol{N}$ \\
\hline Direct management & 116.6 & 41.3 & 0 & 368 & 618 \\
\hline Lease & 159.8 & 50.2 & 24.5 & 426.1 & 935 \\
\hline Concession & 164.9 & 36.1 & 100.2 & 339.2 & 47 \\
\hline Intermediary management/Gerance & 155.2 & 34.2 & 74.2 & 210.8 & 37 \\
\hline Total & 143.56 & 50.88 & 0 & 426.1 & 1637 \\
\hline
\end{tabular}

Source: IFEN and French Water Agencies

The variation in prices across organizational choices may reflect differences in efficiencies in water distribution as well as differences in difficulties in supplying the water. For example, if technical constraints differ systematically across contracts then organizational choices are not random. Furthermore, since contracts are signed at different points in time, we should look at them in the context of an evolving institutional framework. Lastly, the ex post competition level in 2001, along with the time to contract renewal is a source of individual contract heterogeneity that may explain variation in prices. We will further examine the link between contract choice, prices and our propositions about competition and termination effects in our econometric model.

\subsection{Constructed variables}

\section{Prices}

TOTAL Distribution PRICE is the price paid by consumers based on an annual consumption of 120 cubic meters. We incorporate fixed fee into this price but no local or national taxes. OPERATOR Distribution PRICE is the part of the total price that constitutes the revenue of the private operator (the other part is for the local authority). These are the primary explanatory variables of interest.

\section{Governance choices}

The database identifies organizational choices for each local authority (see table 3 for precise definitions of the variables).

In particular, we know specifically what kind of contract the local authorities signed if they decided to externalize the provision of water to a private operator (LEASE, CONCESSION, DiRECT MANAGEMENT $)^{13}$.

\footnotetext{
${ }^{13}$ Intermediary management contracts have been dropped from the analysis because of the small number of observations in the merged sample. However, our results are robust to their exclusion.
} 


\section{Technical differences}

To control for the complexity of providing the service, we use data concerning the size of the population, the size of the network, the density of the distribution network and the investments made or that will be made during the contract duration (NETWORK SIZE, Consumption, Population Growth, Network Renewals, Rate of Leakages). We also use proxy for the complexity of water treatments performed by the operator prior to distribution of the water (Intermediate Treatment, Mixed Treatment, heavy Mixed TREATMEnt, HeAvy TREATMENT). Some of these variables also correctly reflect the level of (specific) investments needed to operate the service - complexity and specific investment are to some extend linked. We expect the price to increase with the complexity of the water treatments and the technological challenges associated with the water network.

We also include variables that reflect the origin of the water (SURFACE WATER). When the water comes from underground, the quality of the water is generally more stable over time, and thus reduces uncertainty about the kind of treatment that will be required over the life of the contract. We expect prices to be lower when water comes from underground.

We also include variables that characterize the distribution network. WATER ABUNDANCE that measures the extent to which the local authority must import water in order to satisfy consumer demand, and should lead to price. The NON TOURIST variable controls for the fact that the infrastructure is non over dimensioned because of seasonal variations in the population.

\section{Contractual choices}

We include RENEGOTIATION to account for contracts that have been renegotiated between 1998 and 2001. Since renegotiation should encourage competition to obtain the contract such recent renegotiation may have an impact on prices observed in 2001. We also controlled for the term of the contract and (TIME TO EXPIRY). We include operator fixed effects (OPERATOR1, OPERATOR2, OPERATOR3, JOINT-VENTURE), and the indicator WASTEWATER for contracts where the same operator is chosen for both water distribution and waste water. Bundling the two activities may create synergies that could be reflected in lower prices.

\section{Institutional environment}

To account for structural change in the institutional rules that govern public-private arrangements in France, we included AFTER 82, a dummy variable for contracts signed after 
the decentralization laws, which give local authorities greater freedom to choose their contractual provisions, and AFTER 93, a dummy variable for contracts signed after the 1993 anti-corruption law, which reduced discretion for local authorities in choosing their operators.

\section{Ex post competition}

We used market shares of French water companies, in each of the 43 regions to construct a Herfindahl index of the concentration of firms in each of these regions. Market shares are calculated as the percentage of the population in a given department being supplied water by a given firm:

$$
\text { HERFINDAHL }=\sum_{i=1}^{n} P_{i}^{2}, \quad \text { with } \sum_{i=1}^{n} P_{i}=1
$$

where $P_{i}$ indicates the market share of a company $i$ in a given department. The higher this index, the lower the potential competition among firms.

However, the Herfindahl index may be a poor measure of ex post competition for at least two reasons. First, it is calculated at the region level and does not take into account the fact that the observed contract is far or near the "frontier" of the region. Thus, a local authority near the frontier of a non-competitive region may well use the competition level that exists in border regions. Second, since it does not take into account competition between organizational modes, namely between public and private management. Indeed, competition is likely to be important between organizational modes. More precisely, we suspect that competition between public and private management may increase as the percentage of the population concerned by direct management in the department increases. Two arguments can be advanced to explain this assertion. First, the areas in which public management is dominant offer more opportunities for the municipalities in private management to integrate a group of local authorities that manages its water service directly, facilitating the transition from private to public management. Second, municipalities using private management may strategically use information on the exploitation costs borne by the municipalities of the neighborhood that manages their water service directly. This information may be used to limit the incumbent's informational advantage with respect to the costs of service provision when negotiating a contract. This implicit yardstick competition, at a local level, between water services managed privately and those managed publicly, may be relevant if 
municipalities situated in the same geographical area share common characteristics (size of population, quality of water, ease of transportation etc...) that make their water service comparable. We include Share DiRect MANAgement as a measure of the competition level between private operators and public management units.

\section{Table 3. Definition of the variables used}

\begin{tabular}{|c|c|c|c|c|c|c|}
\hline & Obs & Mean & Std. Dev. & Min & Max & Definition \\
\hline TOTAL DISTRIBUTION PRICE & 1046 & 148,20 & 49,75 & 18,24 & 373,30 & $\begin{array}{l}\text { Price paid by consumers in euros, for production and distribution of } \\
\text { water, taking into account a fixed fee but not taxes }\end{array}$ \\
\hline $\begin{array}{l}\text { OPERATOR DISTRIBUTION } \\
\text { PRICE }\end{array}$ & 715 & 107,13 & 44,49 & 0,37 & 373,30 & $\begin{array}{l}\text { Part of the price paid by consumers in euros, that is given to the } \\
\text { operator for production and distribution of water, taking into account a } \\
\text { fixed fee but not taxes }\end{array}$ \\
\hline OPERATOR1 & 1046 & 0,17 & 0,38 & 0,00 & 1,00 & Takes value 1 if the company is Operator 1 \\
\hline OPERATOR2 & 1046 & 0,17 & 0,38 & 0,00 & 1,00 & Takes value 1 if the company is Operator 2 \\
\hline OPERATOR3 & 1046 & 0,19 & 0,39 & 0,00 & 1,00 & Takes value 1 if the company is Operator 3 \\
\hline JOINT-VENTURE & 1046 & 0,04 & 0,20 & 0,00 & 1,00 & Takes value 1 if the company is a subsidiary of two operators \\
\hline LEASE & 1046 & 0,64 & 0,48 & 0,00 & 1,00 & Takes value 1 if the water distribution is leased out, 0 otherwise \\
\hline CONCESSION & 1046 & 0,04 & 0,18 & 0,00 & 1,00 & $\begin{array}{l}\text { Takes value } 1 \text { if the water distribution is managed as a concession, } 0 \\
\text { otherwise. }\end{array}$ \\
\hline AFTER 82 & 1046 & 0,57 & 0,49 & 0,00 & 1,00 & Takes value 1 if the contract was signed between 1982 and 1993 \\
\hline AFTER 93 & 1046 & 0,27 & 0,44 & 0,00 & 1,00 & Takes the value 1 if the contract was signed after 1993 \\
\hline RENEGOTIATION & 1046 & 0,14 & 0,35 & 0,00 & 1,00 & Takes value 1 if the contract was renewed between 1998 and 2001 \\
\hline TIME TO EXPIRY & 1046 & 1,36 & 1,09 & 0,00 & 3,09 & Ln(Date of contract end - 2001), 0 for direct public management \\
\hline WASTEWATER & 1046 & 0,23 & 0,42 & 0,00 & 1,00 & $\begin{array}{c}\text { Takes value } 1 \text { if the water distribution contract was signed the same } \\
\text { year as the wastewater treatement contract }\end{array}$ \\
\hline NON TOURIST & 1046 & 0,81 & 0,39 & 0,00 & 1,00 & $\begin{array}{c}\text { Takes value } 1 \text { when the municipality where water is distributed is non } \\
\text { touristic }\end{array}$ \\
\hline WATER ABUNDANCE & 1046 & 0,91 & 0,20 & 0,05 & 1,00 & $\begin{array}{c}\text { Total volume distributed / (total volume distributed + imported } \\
\text { volume) }\end{array}$ \\
\hline RATE OF LEAKAGES & 1046 & $-5,43$ & 1,18 & $-10,29$ & $-1,81$ & $\begin{array}{c}\text { Log (Volume of water leakages/(Volume of produced water + Volume } \\
\text { imported) }\end{array}$ \\
\hline NETWORK SIZE & 1046 & 2,90 & 0,97 & $-0,02$ & 7,27 & Ln (Number of meters of network/number of inhabitants) \\
\hline NETWORK RENEWALS & 1046 & 0,47 & 0,95 & 0,00 & 14,00 & Length of renewed water distribution in $2001(\mathrm{Km})$ \\
\hline CONSUMPTION & 1046 & 4,22 & 0,39 & 1,66 & 6,57 & Ln (Volume of water consumed per inhabitant) \\
\hline POPULATION GROWTH & 1046 & 5,13 & 11,99 & $-40,38$ & 116,67 & Rate of growth of the population between 1990 and $1999(\%)$ \\
\hline SURFACE WATER & 1046 & 0,13 & 0,34 & 0,00 & 1,00 & Takes the value 1 when water origin is surface water \\
\hline I NTERMEDIATE TREATMENT & 1046 & 0,19 & 0,39 & 0,00 & 1,00 & $\begin{array}{c}\text { Takes value } 1 \text { when raw water needs an intermediate desinfection } \\
\text { treatment }\end{array}$ \\
\hline MIXED TREATMENT & 1046 & 0,07 & 0,25 & 0,00 & 1,00 & $\begin{array}{c}\text { Takes value } 1 \text { when raw water needs both soft and intermediate } \\
\text { desinfection treatment (BUT NO heavy desinfection) because water } \\
\text { comes from different sites }\end{array}$ \\
\hline HEAVY MIXED TREATMENT & 1046 & 0,03 & 0,17 & 0,00 & 1,00 & $\begin{array}{c}\text { Takes value } 1 \text { when raw water needs several kinds of desinfection } \\
\text { treatment (soft, intermediate AND COMPULSORILY heavy) because } \\
\text { water comes from different sites }\end{array}$ \\
\hline HEAVY TREATMENT & 1046 & 0,11 & 0,31 & 0,00 & 1,00 & Takes value 1 when raw water needs a heavy desinfection treatment \\
\hline INTERCOMMUNALITY & 1046 & 0,63 & 0,48 & 0,00 & 1,00 & $\begin{array}{c}\text { Takes value } 1 \text { when competencies to control for the service is } \\
\text { transferred to a group of local authorities }\end{array}$ \\
\hline SHARE DIRECT MANAGEMENT & 1046 & 3,16 & 0,81 & 1,71 & 4,49 & $\begin{array}{c}\text { In(Percentage of the population concerned by direct management in } \\
\text { the department) }\end{array}$ \\
\hline $\begin{array}{l}\text { SHARE DIRECT MANAGEMENT * } \\
\text { LEASE }\end{array}$ & 1046 & 1,88 & 1,54 & 0,00 & 4,49 & \\
\hline $\begin{array}{l}\text { SHARE DIRECT MANAGEMENT * } \\
\text { CONCESSION }\end{array}$ & 1046 & 0,09 & 0,48 & 0,00 & 4,04 & \\
\hline $\begin{array}{l}\text { SHARE DIRECT MANAGEMENT * } \\
\text { PPP (Lease or Concession) }\end{array}$ & 1046 & 1,96 & 1,50 & 0,00 & 4,49 & \\
\hline HERFINDAHL & 1046 & 0,45 & 0,13 & 0,26 & 0,87 & dhal indice of the concentration of firms in a given region \\
\hline
\end{tabular}

\subsection{Results and discussion}

We present the results of our regressions in table $4 .{ }^{14}$

The first two columns present the model using the whole sample. We note that the longer the TIME TO EXPIRY for the contract, the higher the price. This is consistent with our

\footnotetext{
${ }^{14}$ A correlation matrix is provided in Appendix 2.
} 
proposition 2. ${ }^{15}$ This result is a striking one that is common to all our estimates. The longer the duration of the contract, the less concerned is the operator by decreasing price in order to enhance his probability to be renewed. The coefficient on AFTER93 is not significant. This suggests that the obligation to organize auctions did not impact on prices even if, depending on specification and used sample, the variable is sometimes slightly significant. Estimates show that governance structures, dates of signatures and technical characteristics of the network are effective in explaining prices. Moreover, the estimates have expected signs. If we believe our explanatory variables reflect costs of private and public operators, we may think that direct public management units and PPPs units basically have the same cost structures.

Column 3 presents estimates using the reduced sample. ${ }^{16}$ This sample permits us to use Herfindahl indices in order to appreciate the impact of ex post competition on prices. We see that coefficient estimates are robust across samples, justifying our use of the small sample. This reinforces our belief that the small sample is not biased as compared to the whole representative sample. The coefficient on HERFINDAHL suggests no direct competition effect on observed prices. Our proposition 1 is thus not confirmed. Nevertheless, our results confirm a competition effect between private operators and public management (Column 4). Our variable SHARE DIRECT MANAGEMENT*PPP is significant. This is also the case for all the other estimates. Those results are the same if we consider only the sub sample reduced on PPPs only (Columns 5 and 6).

Finally, in the two last estimates, we restrict our attention to the part of the price paid by consumers and that constitutes the operator's revenues. Such restriction is justified by the fact that sometimes, especially at the end of contracts duration, the local authority may substitute to the private operator concerning investments to be made and may increase its part of the price. Results do not change.

To resume, the main conclusions of these estimates is that we can observe an inter-modal competition effect (between private operators and public management) that impacts on observed prices. Furthermore, the price is also affected by the time that is remaining before the contract will be renewed.

\footnotetext{
${ }^{15}$ It would have been interesting to test our proposition 2 by estimating cross effects between variables that are appreciating competition and the time that is remaining in the contract. Nevertheless, such estimates are difficult to implement because of colinearity problems.

${ }^{16}$ We have only 1046 observations in the estimates (common observations between the whole sample of 5000 observations and our sample of 1637 observations) but the Herfindahl indices, based on the population in a region, are calculated using the entire sample.
} 
Table 4. Estimates

\begin{tabular}{|c|c|c|c|c|c|c|c|c|}
\hline & $\begin{array}{c}\text { TOTAL } \\
\text { DISTRIBUTION } \\
\text { PRICE } \\
\text { (Whole sample) } \\
\text { (1) }\end{array}$ & $\begin{array}{c}\text { TOTAL } \\
\text { DISTRIBUTION } \\
\text { PRICE } \\
\text { (Whole sample - } \\
\text { PPP only) } \\
\text { (2) }\end{array}$ & $\begin{array}{c}\text { TOTAL } \\
\text { DISTRIBUTION } \\
\text { PRICE } \\
\text { (Merged sample) } \\
\text { (3) }\end{array}$ & $\begin{array}{c}\text { TOTAL } \\
\text { DISTRIBUTION } \\
\text { PRICE } \\
\text { (Merged sample) } \\
\text { (4) } \\
\end{array}$ & $\begin{array}{c}\text { TOTAL } \\
\text { DISTRIBUTION } \\
\text { PRICE } \\
\text { (Merged sample - } \\
\text { PPP only) } \\
\text { (5) }\end{array}$ & $\begin{array}{c}\text { TOTAL } \\
\text { DISTRIBUTION } \\
\text { PRICE } \\
\text { (Merged sample - } \\
\text { PPP only) } \\
\text { (6) } \\
\end{array}$ & \begin{tabular}{|c|} 
OPERATOR \\
DISTRIBUTION \\
PRICE \\
(Merged sample - \\
PPP only) \\
(7) \\
\end{tabular} & $\begin{array}{c}\text { OPERATOR } \\
\text { DISTRIBUTION } \\
\text { PRICE } \\
\text { (Merged sample - } \\
\text { PPP only) } \\
\text { (8) }\end{array}$ \\
\hline OPERATOR 1 & & & $\begin{array}{c}12.678^{*} \\
(5.169)\end{array}$ & $\begin{array}{c}17.277^{* * *} \\
(5.065)\end{array}$ & $\begin{array}{l}13.369^{*} \\
(5.475)\end{array}$ & $\begin{array}{c}17.085^{* *} \\
(5.377)\end{array}$ & $\begin{array}{c}16.285^{* *} \\
(5.025) \\
\end{array}$ & $\begin{array}{l}14.278^{* *} \\
(4.942)\end{array}$ \\
\hline OPERATOR2 & & & $\begin{array}{c}1.263 \\
(4.960)\end{array}$ & $\begin{array}{c}3.716 \\
(4.834)\end{array}$ & $\begin{array}{c}.448 \\
(5.148)\end{array}$ & $\begin{array}{c}5.517 \\
(5.034)\end{array}$ & $\begin{array}{c}1.032 \\
(4.705)\end{array}$ & $\begin{array}{l}-1.235 \\
(4.633)\end{array}$ \\
\hline OPERATOR3 & & & $\begin{array}{c}15.656^{* *} \\
(5.039)\end{array}$ & $\begin{array}{l}18.972^{* * *} \\
(4.927)\end{array}$ & $\begin{array}{l}16.369^{* *} \\
(5.388)\end{array}$ & $\begin{array}{c}19.034^{* * *} \\
(5.274)\end{array}$ & $\begin{array}{c}7.515 \\
(4.930) \\
\end{array}$ & $\begin{array}{c}8.108+ \\
(4.835) \\
\end{array}$ \\
\hline J OINT-VENTURE & & & $\begin{array}{c}33.950 * * * \\
(8.521)\end{array}$ & $\begin{array}{l}35.555^{* * * *} \\
(8.324)\end{array}$ & $\begin{array}{l}25.741^{* *} \\
(9.501)\end{array}$ & $\begin{array}{c}29.591^{* *} \\
(9.290) \\
\end{array}$ & $\begin{array}{l}20.671^{*} \\
(8.683)\end{array}$ & $\begin{array}{l}20.787^{*} \\
(8.514) \\
\end{array}$ \\
\hline LEASE & $\begin{array}{c}22.62 * * * \\
(3.34) \\
\end{array}$ & $\begin{array}{c}-21.45^{* * *} \\
(4.06) \\
\end{array}$ & $\begin{array}{c}13.929+ \\
(7.569)\end{array}$ & $\begin{array}{c}24.005+ \\
(14.504)\end{array}$ & $\begin{array}{l}-21.398^{* *} \\
(8.075)\end{array}$ & $\begin{array}{c}-16.147^{*} \\
(7.926)\end{array}$ & $\begin{array}{c}-27.350 * * * \\
(7.408) \\
\end{array}$ & $\begin{array}{l}-136.311^{* * *} \\
(21.957) \\
\end{array}$ \\
\hline CONCESSION & $\begin{array}{c}39.07 * * * \\
(5.29)\end{array}$ & (dropped) & $\begin{array}{l}26.662 * \\
(11.188)\end{array}$ & $\begin{array}{l}31.249+ \\
(16.502)\end{array}$ & (dropped) & (dropped) & (dropped) & (dropped) \\
\hline AFTER 82 & $\begin{array}{l}-1,18 \\
(2.50)\end{array}$ & $\begin{array}{l}-1.84 \\
(2.59)\end{array}$ & $\begin{array}{l}-3.564 \\
(4.397)\end{array}$ & $\begin{array}{l}-4.965 \\
(4.281)\end{array}$ & $\begin{array}{l}-4.139 \\
(4.551)\end{array}$ & $\begin{array}{l}-5.736 \\
(4.447)\end{array}$ & $\begin{array}{l}7.188+ \\
(4.156)\end{array}$ & $\begin{array}{c}5.135 \\
(4.094)\end{array}$ \\
\hline AFTER 93 & $\begin{array}{l}2.49 \\
(2.47) \\
\end{array}$ & $\begin{array}{l}-2.49 \\
(2.56)\end{array}$ & $\begin{array}{l}-5.903 \\
(4.104)\end{array}$ & $\begin{array}{l}-8.384 * \\
(4.009)\end{array}$ & $\begin{array}{l}-5.577 \\
(4.257)\end{array}$ & $\begin{array}{r}-8.191+ \\
(4.175) \\
\end{array}$ & $\begin{array}{c}-11.130 * * \\
(3.902)\end{array}$ & $\begin{array}{l}-9.736^{*} \\
(3.836)\end{array}$ \\
\hline RENEGOTIATION & $\begin{array}{c}-7.00 * * * \\
(2.72)\end{array}$ & $\begin{array}{l}-6.80^{*} \\
(2.79) \\
\end{array}$ & $\begin{array}{c}-8.174+ \\
(4.639) \\
\end{array}$ & $\begin{array}{l}-3.913 \\
(4.551) \\
\end{array}$ & $\begin{array}{l}-7.597 \\
(4.760) \\
\end{array}$ & $\begin{array}{l}-3.879 \\
(4.685) \\
\end{array}$ & $\begin{array}{c}-7.903+ \\
(4.379) \\
\end{array}$ & $\begin{array}{l}-7.635+ \\
(4.294) \\
\end{array}$ \\
\hline TIME TO EXPIRY & $\begin{array}{c}5.66 * * * \\
(1.35)\end{array}$ & $\begin{array}{c}5.69 * * * \\
(1.39)\end{array}$ & $\begin{array}{c}10.039 * * * \\
(2.526)\end{array}$ & $\begin{array}{l}9.976 * * * \\
(2.459)\end{array}$ & $\begin{array}{l}8.905^{* * *} \\
(2.644)\end{array}$ & $\begin{array}{c}9.096 * * * \\
(2.580)\end{array}$ & $\begin{array}{c}10.810^{* * * *} \\
(2.411)\end{array}$ & $\begin{array}{l}10.193^{* * *} \\
(2.367)\end{array}$ \\
\hline WASTE WATER & $\begin{array}{l}-2.95 \\
(2.02) \\
\end{array}$ & $\begin{array}{c}-1.76 \\
(2.14) \\
\end{array}$ & $\begin{array}{l}-4.655 \\
(3.462) \\
\end{array}$ & $\begin{array}{l}-3.571 \\
(3.372)\end{array}$ & $\begin{array}{l}-1.011 \\
(3.698)\end{array}$ & $\begin{array}{l}-0.272 \\
(3.609) \\
\end{array}$ & $\begin{array}{c}0.768 \\
(3.373)\end{array}$ & $\begin{array}{c}1.306 \\
(3.309)\end{array}$ \\
\hline NON TOURIST & $\begin{array}{c}-5.59 * * * \\
(2.17)\end{array}$ & $\begin{array}{c}-6.62 * * \\
(2.73) \\
\end{array}$ & $\begin{array}{l}-7.088^{*} \\
(3.303) \\
\end{array}$ & $\begin{array}{l}-6.418^{*} \\
(3.213) \\
\end{array}$ & $\begin{array}{l}-6.217 \\
(4.165) \\
\end{array}$ & $\begin{array}{l}-5.842 \\
(4.063) \\
\end{array}$ & $\begin{array}{l}-5.117 \\
(3.797) \\
\end{array}$ & $\begin{array}{l}-7.770^{*} \\
(3.757) \\
\end{array}$ \\
\hline WATER ABUNDANCE & $\begin{array}{c}-10.24 * * * \\
(3.46)\end{array}$ & $\begin{array}{c}-10.96 * * * \\
(4.13)\end{array}$ & $\begin{array}{c}-10.635+ \\
(6.301)\end{array}$ & $\begin{array}{l}-13.611 * \\
(6.152)\end{array}$ & $\begin{array}{l}-8.623 \\
(7.812)\end{array}$ & $\begin{array}{c}-15.434^{*} \\
(7.706)\end{array}$ & $\begin{array}{l}-5.353 \\
(7.203)\end{array}$ & $\begin{array}{c}-9.879 \\
(7.115)\end{array}$ \\
\hline RATE OF LEAKAGES & $\begin{array}{c}-1.42^{*} \\
(0.86)\end{array}$ & $\begin{array}{c}-2.34^{*} \\
(1.24)\end{array}$ & $\begin{array}{l}-2.355 \\
(1.561)\end{array}$ & $\begin{array}{l}-1.743 \\
(1.523)\end{array}$ & $\begin{array}{l}-3.849+ \\
(2.309)\end{array}$ & $\begin{array}{l}-3.044 \\
(2.256)\end{array}$ & $\begin{array}{c}-6.178 * * \\
(2.109)\end{array}$ & $\begin{array}{l}-5.828^{* *} \\
(2.069)\end{array}$ \\
\hline SIZE NETWORK & $\begin{array}{c}15.44 * * * \\
(1.21)\end{array}$ & $\begin{array}{c}20.98^{* * *} \\
(1.68)\end{array}$ & $\begin{array}{c}16.292^{* * *} \\
(2.151)\end{array}$ & $\begin{array}{l}16.998^{* * *} \\
(2.093)\end{array}$ & $\begin{array}{l}21.262 * * * \\
(3.110)\end{array}$ & $\begin{array}{c}21.442 * * * \\
(3.034)\end{array}$ & $\begin{array}{l}-2.799 \\
(2.836) \\
\end{array}$ & $\begin{array}{l}-1.406 \\
(2.793) \\
\end{array}$ \\
\hline NETWORK RENEWALS & $\begin{array}{l}1.13^{* *} \\
(0.55)\end{array}$ & $\begin{array}{c}0.69 \\
(0.69)\end{array}$ & $\begin{array}{c}0.299 \\
(1.312)\end{array}$ & $\begin{array}{c}1.352 \\
(1.283)\end{array}$ & $\begin{array}{c}0.974 \\
(1.686)\end{array}$ & $\begin{array}{c}1.850 \\
(1.651)\end{array}$ & $\begin{array}{l}2.782+ \\
(1.543)\end{array}$ & $\begin{array}{l}2.532+ \\
(1.514)\end{array}$ \\
\hline CONSUMPTION & $\begin{array}{c}-14.72^{* * *} * \\
(2.7)\end{array}$ & $\begin{array}{c}-21.75^{* * *} * \\
(2.84)\end{array}$ & $\begin{array}{c}-14.283^{* * *} * \\
(3.455)\end{array}$ & $\begin{array}{l}-12.694^{* * *} \\
(3.366) \\
\end{array}$ & $\begin{array}{l}-15.403^{* *} \\
(4.669)\end{array}$ & $\begin{array}{c}-14.031^{* *} \\
(4.560) \\
\end{array}$ & $\begin{array}{l}-0.667 \\
(4.262) \\
\end{array}$ & $\begin{array}{l}-1.761 \\
(4.184) \\
\end{array}$ \\
\hline POPULATION GROWTH & $\begin{array}{c}-2.24 * * * \\
(0.06)\end{array}$ & $\begin{array}{c}-0.35^{* * *} \\
(0.08)\end{array}$ & $\begin{array}{c}-0.181+ \\
(0.105)\end{array}$ & $\begin{array}{l}-0.091 \\
(0.103)\end{array}$ & $\begin{array}{l}-0.221 \\
(0.136)\end{array}$ & $\begin{array}{c}-0.129 \\
(0.133)\end{array}$ & $\begin{array}{c}0.002 \\
(0.124) \\
\end{array}$ & $\begin{array}{l}-0.038 \\
(0.122) \\
\end{array}$ \\
\hline SURFACE WATER & $\begin{array}{c}19.11^{* * *} \\
(2.53)\end{array}$ & $\begin{array}{c}21.01 * * * \\
(3.21)\end{array}$ & $\begin{array}{c}17.919^{* * *} \\
(4.505)\end{array}$ & $\begin{array}{l}17.715^{* * *} \\
(4.381)\end{array}$ & $\begin{array}{l}21.685^{* * *} \\
(5.664)\end{array}$ & $\begin{array}{c}22.027^{* * *} \\
(5.525)\end{array}$ & $\begin{array}{c}8.326 \\
(5.164)\end{array}$ & $\begin{array}{l}10.998^{*} \\
(5.089)\end{array}$ \\
\hline $\begin{array}{l}\text { INTERMEDIATE } \\
\text { TREATMENT }\end{array}$ & $\begin{array}{c}9.93^{* * *} \\
(2.03)\end{array}$ & $\begin{array}{c}11.09 * * * \\
(2.67)\end{array}$ & $\begin{array}{c}13.572^{* * *} \\
(3.614)\end{array}$ & $\begin{array}{l}11.819^{* * *} \\
(3.523)\end{array}$ & $\begin{array}{l}13.472 * * \\
(4.260)\end{array}$ & $\begin{array}{c}11.387^{* *} \\
(4.170)\end{array}$ & $\begin{array}{c}13.187^{* * *} \\
(3.898) \\
\end{array}$ & $\begin{array}{c}9.241^{*} \\
(3.895) \\
\end{array}$ \\
\hline MIXED TREATMENT & $\begin{array}{c}11.94^{* * *} \\
(3.1)\end{array}$ & $\begin{array}{c}7.88^{*} \\
(4.07)\end{array}$ & $\begin{array}{l}12.346^{*} \\
(5.141)\end{array}$ & $\begin{array}{l}15.492^{* *} \\
(5.018)\end{array}$ & $\begin{array}{c}5.628 \\
(6.622)\end{array}$ & $\begin{array}{c}8.343 \\
(6.475)\end{array}$ & $\begin{array}{c}-11.212+ \\
(6.052)\end{array}$ & $\begin{array}{l}-15.440 * \\
(5.989)\end{array}$ \\
\hline HEAVY MIXED TREATMENT & $\begin{array}{c}17.35^{* * *} \\
(3.42)\end{array}$ & $\begin{array}{c}14.14^{* * *} \\
(4.11)\end{array}$ & $\begin{array}{c}40.665^{* * *} \\
(7.308)\end{array}$ & $\begin{array}{l}39.393^{* * *} \\
(7.110)\end{array}$ & $\begin{array}{l}46.653^{* * *} \\
(9.490)\end{array}$ & $\begin{array}{c}43.509 * * * \\
(9.272)\end{array}$ & $\begin{array}{c}29.337 * * * \\
(8.666)\end{array}$ & $\begin{array}{l}26.758^{* *} \\
(8.512)\end{array}$ \\
\hline HEAVY TREATMENT & $\begin{array}{c}13.93^{* * *} \\
(2.37)\end{array}$ & $\begin{array}{c}13.42 * * * \\
(2.89)\end{array}$ & $\begin{array}{l}9.569 * \\
(4.518) \\
\end{array}$ & $\begin{array}{r}9.530^{*} \\
(4.395) \\
\end{array}$ & $\begin{array}{l}13.570^{*} \\
(5.570)\end{array}$ & $\begin{array}{l}13.764 * \\
(5.432) \\
\end{array}$ & $\begin{array}{l}11.804^{*} \\
(5.078)\end{array}$ & $\begin{array}{l}11.635^{*} \\
(4.979) \\
\end{array}$ \\
\hline REGIONAL EFFECTS & Included & Included & Included & Included & Included & Included & Included & Included \\
\hline HERFINDAHL & & & $\begin{array}{c}3.558 \\
(11.576)\end{array}$ & $\begin{array}{l}-10.461 \\
(11.402)\end{array}$ & $\begin{array}{c}-1.672 \\
(14.385)\end{array}$ & $\begin{array}{l}-13.575 \\
(14.174)\end{array}$ & $\begin{array}{c}18.085 \\
(13.248)\end{array}$ & $\begin{array}{c}14.844 \\
(13.005)\end{array}$ \\
\hline $\begin{array}{l}\text { SHARE DIRECT } \\
\text { MANAGEMENT }\end{array}$ & & & & $\begin{array}{l}-16.065^{* * *} \\
(3.498)\end{array}$ & & & & \\
\hline $\begin{array}{c}\text { SHARE DIRECT } \\
\text { MANAGEMENT*LEASE }\end{array}$ & & & & & & & & $\begin{array}{l}-7.852^{*} \\
(3.131)\end{array}$ \\
\hline $\begin{array}{c}\text { SHARE DIRECT } \\
\text { MANAGEMENT*CONCESSI }\end{array}$ & & & & & & & & $\begin{array}{l}-51.061 * * * \\
(8.251)\end{array}$ \\
\hline $\begin{array}{c}\text { SHARE DIRECT } \\
\text { MANAGEMENT*PPP }\end{array}$ & & & & $\begin{array}{l}-5.267 \\
(3.589)\end{array}$ & & $\begin{array}{c}-19.903^{* * *} \\
(3.361)\end{array}$ & $\begin{array}{c}-10.808^{* * *} \\
(3.141)\end{array}$ & \\
\hline INTERCOMMUNALITY & $\begin{array}{c}16,14 * * * \\
(1,61)\end{array}$ & $\begin{array}{c}13,82 * * * \\
(2,17)\end{array}$ & $\begin{array}{c}20.999 * * * \\
(2.841)\end{array}$ & $\begin{array}{l}19.579 * * * \\
(2.801)\end{array}$ & $\begin{array}{l}24.651 * * * \\
(3.908)\end{array}$ & $\begin{array}{c}23.356^{* * * *} \\
(3.818)\end{array}$ & $\begin{array}{c}17.237 * * * \\
(3.569)\end{array}$ & $\begin{array}{l}15.659 * * * \\
(3.512)\end{array}$ \\
\hline CONSTANT & $\begin{array}{c}145.26 * * * \\
(16.82)\end{array}$ & $\begin{array}{c}220,29 * * * \\
-24,37\end{array}$ & $\begin{array}{c}124.258^{* * *} \\
(25.125) \\
\end{array}$ & $\begin{array}{l}178.934 * * * \\
(27.356)\end{array}$ & $\begin{array}{l}161.015^{* * *} \\
(36.956)\end{array}$ & $\begin{array}{c}223.975 * * * \\
(37.580)\end{array}$ & $\begin{array}{c}139.951^{* * *} \\
(35.125)\end{array}$ & $\begin{array}{l}251.888 * * * \\
(40.489)\end{array}$ \\
\hline$r^{2}$ & 0.41 & 0.41 & 0.453 & 0.484 & 0.422 & 0.451 & 0.429 & 0.452 \\
\hline $\mathrm{N}$ & 2898 & 1783 & 1046 & 1046 & 702 & 702 & 697 & 697 \\
\hline
\end{tabular}

Standard Error in parentheses. $+0.10 * 0.05 * 0.01 * * * 0.001$

If we now turn to the impact of the organizational choice on prices we can note positive coefficients for lease and concession contracts when we consider whole samples (when public utilities are the reference group), and negative coefficients for lease contracts when the sample is reduced to PPP agreements and concessions units are the reference group. The direct effect on price of choosing one governance structure over another should be considered 
in conjunction with the impact of the time remaining in the contract (reducing the efficiency of lease contracts compared to public utilities in PPP reduced samples). Furthermore, although at first glance, public utilities seem to offer lower prices, the impact of competition (intra- and inter-modal) and the upcoming termination may help to nuance their apparent superiority.

Nevertheless, we face a selection bias when considering the question of what is the best organizational choices regarding observed prices. Organizational choices are not randomly chosen. This selection bias is addressed elsewhere (Chong-Huet-Saussier 2005). But it should not impact our main conclusions concerning the way prices evolve in PPPs contracts. Whatever the reasons for which local authorities decided to organize distribution of water with a particular contractual arrangement, this should impact on observed prices but not on the way prices evolve.

\section{Conclusion}

In this paper, we argued that it may be misleading to focus only on the way franchise contracts are auctioned without looking at the ex post stage of such contracts. In this spirit, we explored the relationships between prices charged by private operators and ex post competition in water contracting. Our main finding is when operators have a monopoly for the entire length of the contract their prices are not mitigated by a direct intra-modal "competition effect". This can be explained by the way we calculated our Herfindahl indices, focusing on regions. This can also reflect the absence of competition on this concentrated market. However, there exist an inter-modal competition effect, between private operators and public management units that has a significant impact on prices. We also found a "termination effect", reflecting the fact that prices are decreasing when the contract is close to being renewed, and hence re-auctioned.

Our results shed light on the necessity $1 /$ to analyze the way local public services are organized as a whole, not focusing only on the auction ex ante stage 2 / of considering the way informal ex post mechanisms may constrain opportunistic behaviors and the fact that the auction for franchise contracts should be designed accordingly. 


\section{References}

Athias L., Saussier S, 2005, "Contractual Design of Toll Adjustment Processes in Infrastructure Concession Contracts. What Matters?", Working Paper ATOM, University of Paris I Sorbonne \& http://ssrn.com/abstract=828944.

Bajari P, McMillan R. and Tadelis S, 2003, Auctions versus Negotiations in Procurement: An Empirical Analysis. NBER Working Papers 9757.

Bajari P, Tadelis S, 2001, Incentives versus Transaction Costs: a Theory of Procurement Contracts, Rand Journal of Economics, 32, 387-407.

Bajari P, Houghton S. and Tadelis S, 2004, “ “ Working Paper.

Bennett J., Iossa E., 2004, "Building and Managing Facilities for Public Services", Unpublished Manuscript.

Boyco M., Shleifer A., Vishny R., 1996 “A Theory of Privatization”, The Economic Journal, 106, 309-319.

Boyer M. et Garcia S., 2004, Régulation et Mode de Gestion : une étude économétrique sur les prix et la performance dans le secteur de l'eau potable, working paper.

Chadwick E. 1859, "Results of Different Principles of Legislation in Europe." Journal of the Royal Statistical Society, series A22.

Chong E., Huet F, Saussier S. 2005, "Public-Private Partnerships and Prices: Evidence From Water Distribution in France", Review of Industrial Organization, Forthcoming.

Chong E. and Huet F., 2005, "Franchise Bidding for Natural Monopolies, Physical Assets Valuation at Contract's Renewal and Incentives to Invest: the Case of the Water Sector in France" Working Paper.

Crocker K.J., Masten S.E., 1991 "Pretia ex Machina?: Prices and Process in Long Term Contracts", Journal of Law and Economics, 34, 64-69

Crocker K.J., Reynolds K.J., 1993 "The Efficiency of Incomplete Contracts: An Empirical Analysis of Air Force Engine Procurement.", Rand Journal of Economics, 24, 126-146.

Cour des Comptes, 1997, La gestion des services publics locaux d'eau et d'assainissement, Rapport Public, Paris, Editions du Journal Officiel.

Cour des Comptes, 2003, La gestion des services publics d'eau et d'assainissement, Rapport Public, http://www.ccomptes.fr/Cour-des-comptes/publications/rapports/cdc55.htm

Demsetz H.,1968, “Why Regulate Utilities?”, Journal of Law and Economics 11, 55-66.

Engel E., Fisher R. \& Galetovic A. [1997], "Highway Franchising: Pitfalls and Opportunities“, American Economic Review, 87, 68-72.

Garrouste P., Saussier S., 2005, "Looking for a theory of the firm: future challenges", Journal of Economic Behavior and Organization, 58 (2), 178-199.

Gibbons R., 2005, "Contracting for Control : Decision Rights, Payoff Rights and Relationships in Firms, Contracts and other Governance Structures", working paper.

Grout, P.A., 1997, “The economics of Private Finance Initiative”, Oxford Review of Economic Policy, 13, 4, 53-66.

Guasch J.L., Laffont J.J., Straub S. 2004 "Renegotiation of Concession Contracts in Latin America", working paper. 
Guérin-Schneider L., Breuil L., Bonnet Fr., 2003, « Dix ans de loi Sapin dans les services d'eau et d'assainissement : évolutions et perspectives du modèle de délégation à la française ». Responsabilité et Environnement, 31, 44-57.

Hamilton, B.A., Nickerson, J.A., 2003, Correcting for Endogeneity in Strategic Management Research, Strategic Organization, 1, 53-80.

Hart O.D. 2003, Incomplete Contract and Public Ownership: Remarks, and an Application to Public-Private Partnerships, The Economic Journal, 113, 69-76.

Hart O.D., Shleifer A., Vishny R.W., 1997, The Proper Scope of Government: Theory and Application to Prisons, Quarterly Journal of Economics, CXII, 1127-1162.

Huet F, Saussier S, 2003, “The Provision of Public Interest Services through Private Law Contracts", European Business Organization Law Review, 4, 403-428.

Laffont J.J., 2000, "Etapes vers un Etat moderne : une analyse économique", Rapport Conseil d'Analyse Economique, Etat et Gestion Publique.

Littlechild S.C., 2002, "Competitive Bidding for a Long-Term Electricity Distribution Contract", Review of Network Economics 1, 1-38.

Megginson W.L., Netter J.M., 2001, "From State to Market : a Survey of Empirical Studies on Privatization", Journal of Economic Literature, XXXIX, 321-389.

Ménard C., Saussier S., 2002, Contractual Choices and Performances: The Case of Water distribution in France, in Economics of Contracts: Theories and Applications, Cambridge University Press, 440-463.

Ménard C., Saussier S., 2003, "La délégation de service public comme mode organisationnel efficace de la distribution d'eau en France : Théories et évidences empiriques", Economie Publique, 12, 99-129.

Ménard C., Staropoli C., Saussier S., 2003, "L'impact des contraintes institutionnelles sur les choix contractuelles des collectivités locales", Annuaire des Collectivités Locales, CNRS Editions, 109-118.

Poppo L., Zenger T. 2002, "Do Formal Contracts and Relational Governance Function as Substitute or Complement”, Strategic Management Journal, 23, 707-725.

Saussier S., 2000, «Transaction Costs and Contractual Completeness», Journal of Economic Behavior and Organization, 42, 189-206.

Williamson O.E.,1976, "Franchise Bidding for Natural Monopolies - In General and with Respect to CATV". Bell Journal of Economics 7, 73-104.

Williamson O.E.,1996, The Mechanisms of Governance, Oxford University Press.

Williamson O.E., 1999, Public and Private Bureaucracies: A Transaction Cost Economics Perspective, Journal of Law, Economics and Organization, 15, 306-342.

Yvrande A., Saussier S. 2004, Governance Choices and Performances, in New Ideas in Contracting and Organizational Economics Research, Ed. J. Harvey, Norwell MA: Kluwer Academic Publishers

Zupan M.A., 1989a., "Cable Franchise Renewals : Do Incumbent Firms Behave Opportunistically ?" Rand Journal of Economics 20, 473-482.

Zupan M.A., 1989b, "The Efficacy of Franchise Bidding Schemes in the Case of Cable Television: Some Systematic Evidence”, Journal of Law and Economics, 32, 401-456. 
Appendix 1.

Graph 1. Date of signature of the contracts (702 observations)

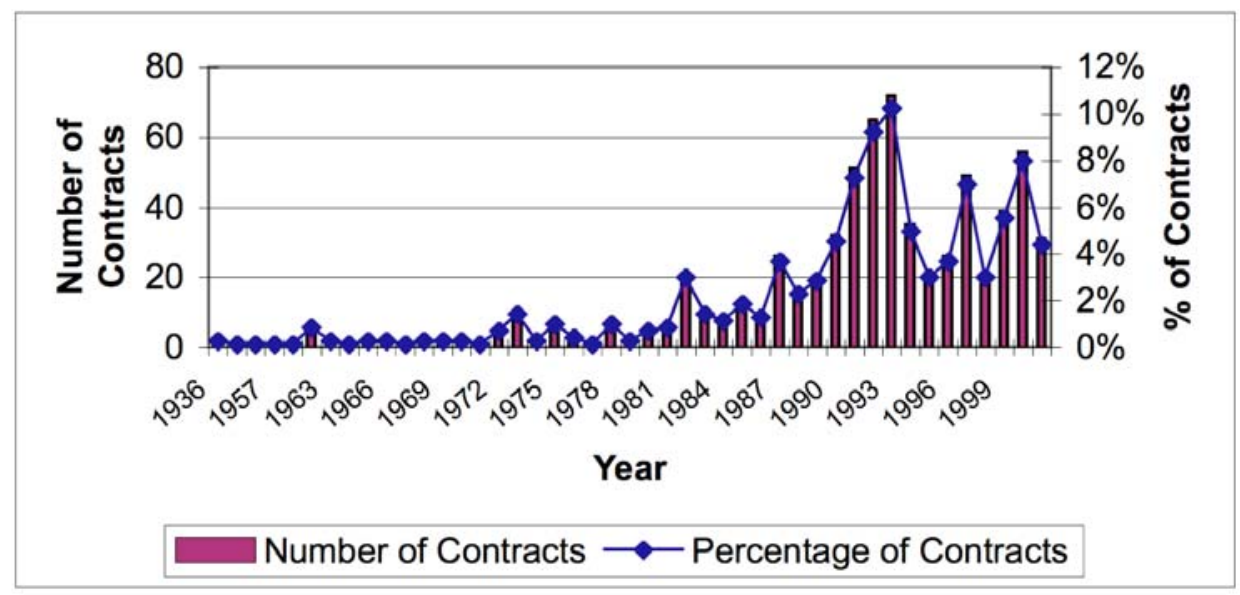

Graph 2. Contract duration (702 observations)

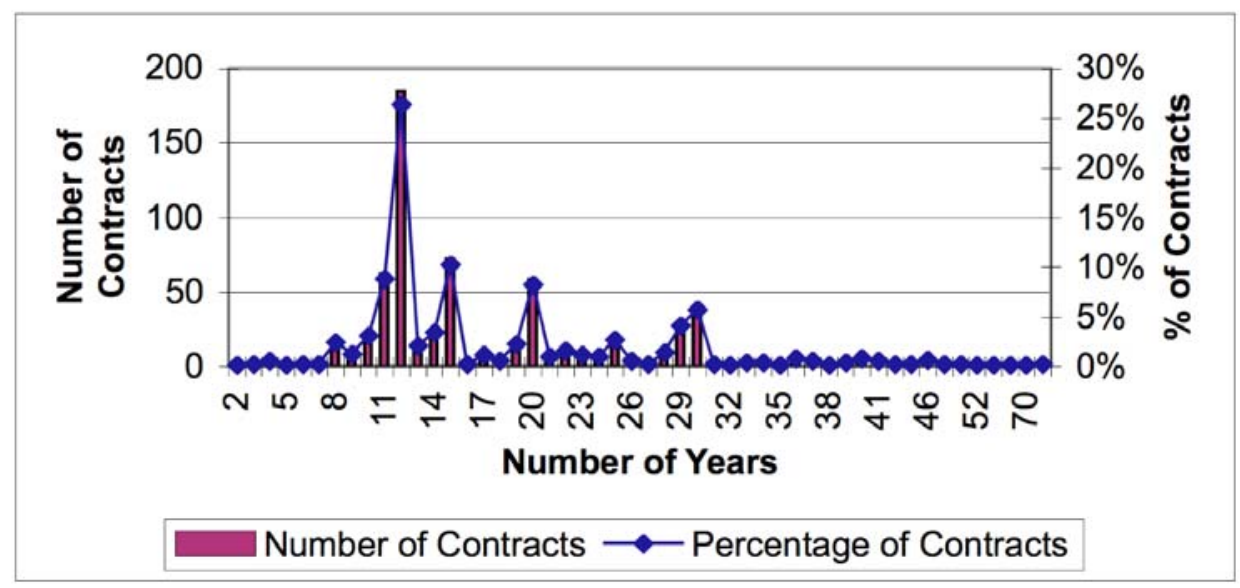

Graph3. Contract year termination (702 Observations)

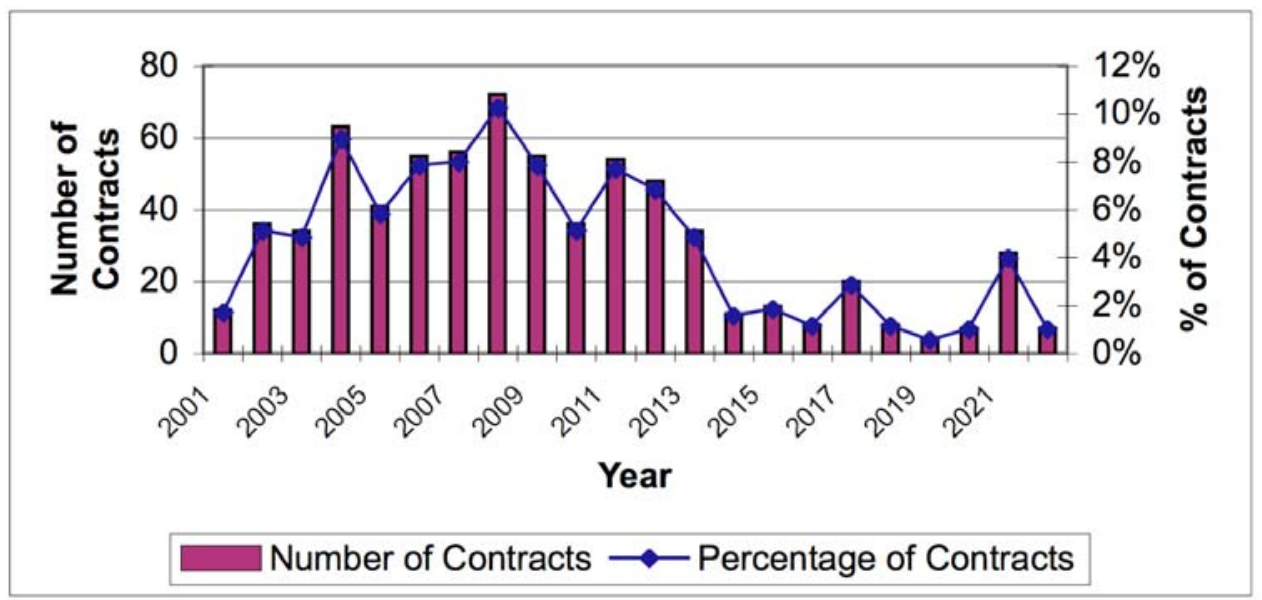




\section{Appendix 2. Correlation Matrix}

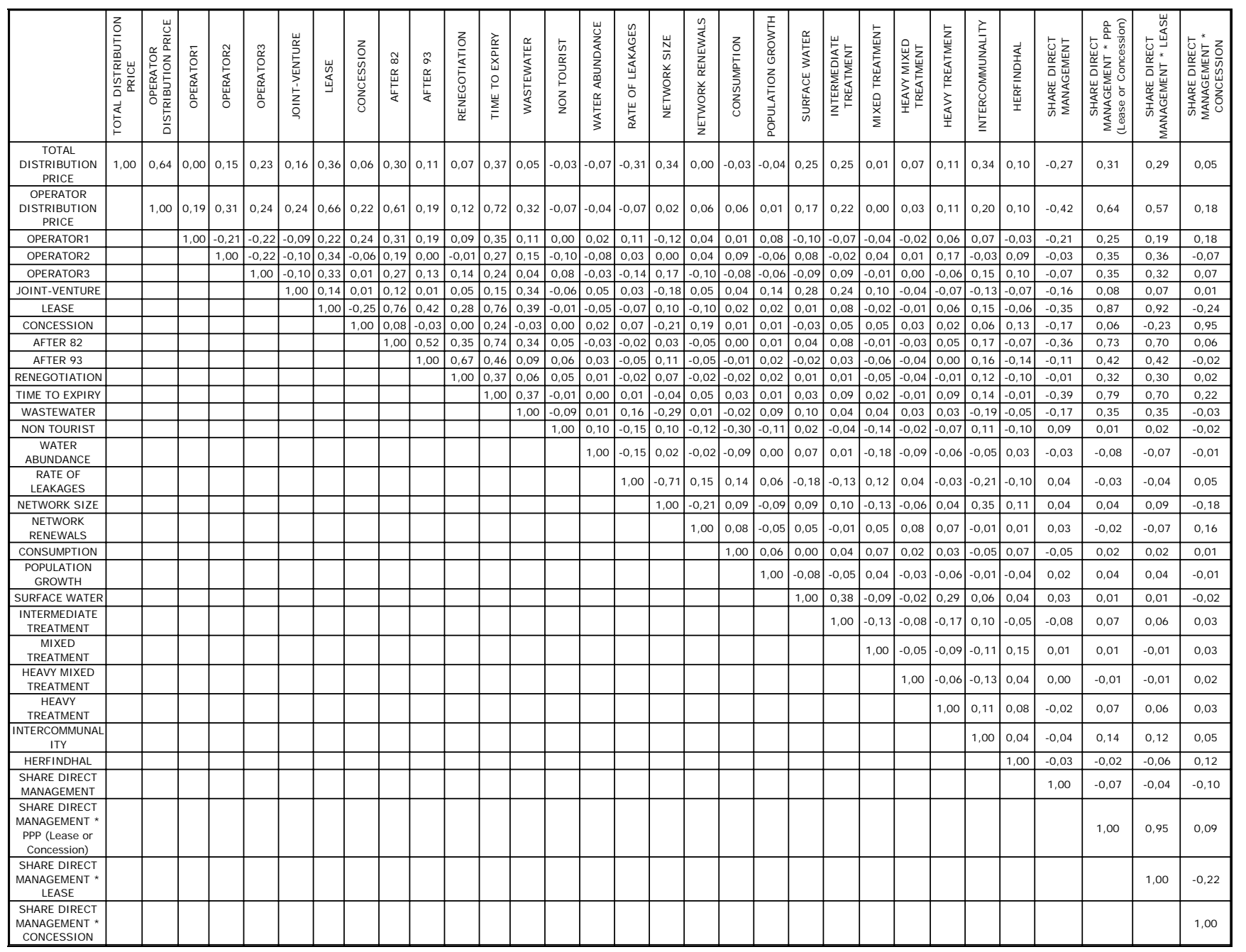

